\title{
Giant Vulvar Lipoma in a Yong Woman
}

Diarra Lasseny ${ }^{1 *}$, Dembele Bertin ${ }^{1}$, Konate Karim ${ }^{1}$, Toure $\mathrm{Mk}^{1}$, Coulibaly $\mathrm{M}^{1}$, Toure $\mathrm{O}^{1}$, Diallo $\mathrm{O}^{1}$, Tangara $\mathrm{K}^{1}$, Bengaly $\mathrm{B}^{2}$, Traore $\mathrm{D}^{2}$

${ }^{1}$ Hôpital de dermatologie de Bamako HBD (EX-CNAM/CVD Mali)

${ }^{2}$ Service de chirurgie générale du POINT G

DOI: $10.36347 /$ sasjs.2020.v06i01.003

| Received: 15.01.2020 | Accepted: 22.01.2020 | Published: 26.01.2020

*Corresponding author: Diarra Lasseny

Abstract

Review Article

Lipomas are benign tumors developed at the expense of adipocytes. They are very rarely located at the level of the vulva. The lipoma is called "giant" when the excision piece exceeds $5 \mathrm{~cm}$ in diameter and $1 \mathrm{~kg}$ in weight. We report, through this observation, a rare case of giant lipoma located at the level of the vulva in a patient of 35 years evolving for three years. Doppler ultrasound found a benign tumor. The surgical excision of the tumor with his pedicle allowed seeing the fat well encapsulated. The lipoma weighed 2000 grams and measured 22x18 cm. The histology of the operative specimen confirmed the lipoma. The postoperative course was simple with no discomfort.

Keywords: Diagnosis, lipoma giant, vulva, Bamako/Mali.

Copyright @ 2020: This is an open-access article distributed under the terms of the Creative Commons Attribution license which permits unrestricted use, distribution, and reproduction in any medium for non-commercial use (NonCommercial, or CC-BY-NC) provided the original author and source are credited.

\section{INTRODUCTION}

Lipoma is defined as a benign mesenchymal tumor composed of mature fat cells without cellular atypia. It is very common, of subcutaneous seat as a rule and only causes cosmetic damage [1, 2]. Lipoma represents 16 to $50 \%$ of all benign soft tissue tumors [3]. It is described as "giant" when it measures at least $10 \mathrm{~cm}$ in diameter and its mass exceeds $1 \mathrm{~kg}$ [4]. Is a giant lipoma rare [5]. We report an observation of an unusual location of a giant vulvar lipoma and we discuss the clinical, diagnostic and therapeutic features of this rare pathology.

\section{OBSERVATION}

This was a 35-year-old Mauritanian patient; having 6 children, housewife with no particular medical and surgical history. She has complained of a painless vulvar swelling. The onset of the disease dated about 3 years ago by the spontaneous appearance of a small painless swelling in the left vulva. This swelling gradually increased in volume with an acceleration of growth during the last pregnancy to reach its current size. The delivery took place vaginally without complications. On admission, clinical examination showed a mobile tumor with a broad pediculate base, firm, painless, $22 \mathrm{~cm}$ long axis, occupying the anterointernal part of the left vulva. The contours of the mass were bumpy (Figure 1). She had had a superficial ulceration of less than one $\mathrm{cm}$ due to friction. There were no inguinal nor vulvar lymph nodes. The rest of the clinical examination was normal.

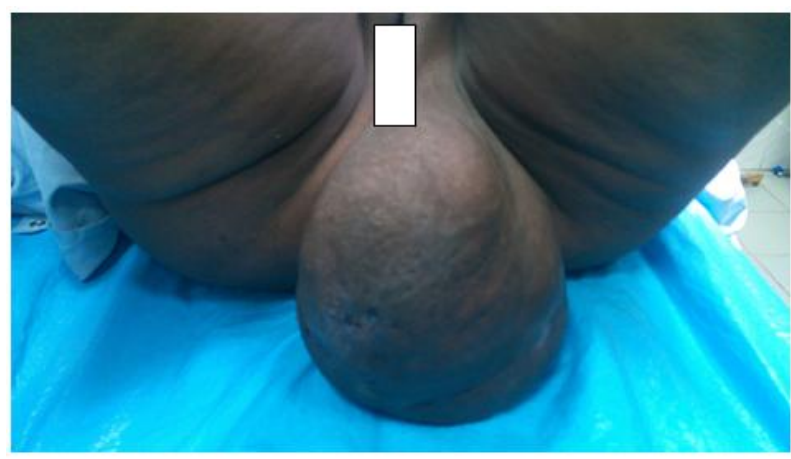

Fig-1: Appearance of the tumor before surgery

Doppler ultrasound found a heterogeneous benign mass, left-sided vulvar implantation with a weak resistance arterial pedicle. The preoperative assessment was relatively normal: A+ blood group, a hemoglobin level of $11.9 \mathrm{~g}$, a hematocrit level of $37.2 \%$, and a fasting blood sugar level of $0.94 \mathrm{~g} / 1$. preoperatively, the skin was neither inflammatory nor adherent to the tumor. The treatment undertaken was a complete surgical resection in blockage of the mass under local anesthesia. The surgery lasted 45 minutes. After the excision, the piece measured $22 \mathrm{~cm}$; and weighed 2 kilograms (Figure 2). An operative piece dissection in the operating room revealed lobulated yellow adipose 
tissue without hemorrhage or necrosis. An anatomopathological examination of the piece concluded an angiolipoma.

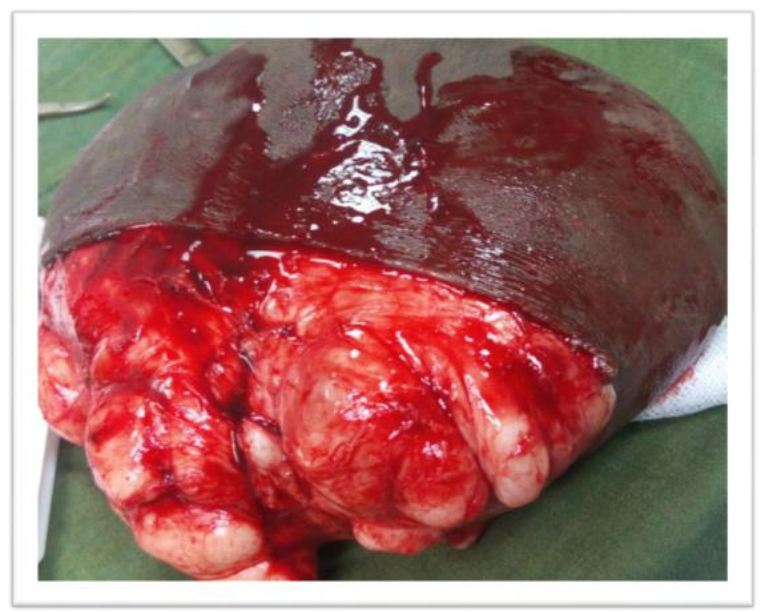

Fig-2: Macroscopic aspect of the anatomical piece

The operative course was quite simple.The heaviness and discomfort was disappeared.

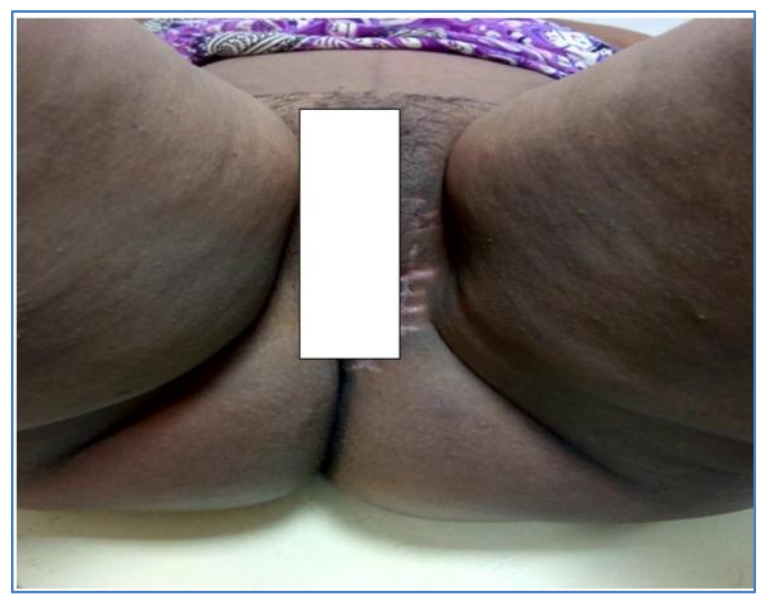

Fig-3: 15 days after the excision

\section{DISCUSSION}

Lipoma is a benign tumor made up of mature fat $[1,2]$. Lipomas are frequent tumors, often overlooked when they cause no aesthetic damage or when they are asymptomatic. Giant lipomas of the vulva are relatively rare. In the literature review, Hasija Shweta et al. reported 10 cases of vulvar lipoma [5]. Giant lipomas, regardless of location, affect women more often than men with a sex ratio 0.2 in favor of women and occur between the fourth and the fifth decade of life [6, 7]. Generally, the duration of evolution of a lipoma is very variable from one case to another, ranging from 2 months to 40 years [6]. For vulvar localization, this evolution also varies according to the authors. In the case that we report, this duration of evolution was 3 years, which was similar to that reported by Ouadii Al Haderi et al. [8]. On the other hand, for the study by Sofia Jayi et al [9], the period was one year, 10 months for D. M. Sherer et al. [10]. Ultrasound is the gold standard for the diagnosis of superficial and extremity lipomas. It shows a welldefined oval or elongated formation with a long axis parallel to the skin plane. Its echogenicity is variable depending on the interfaces between the fatty tissue and the connective elements. It appears hypoechoic or more typically hyperechoic with a homogeneous or discreetly heterogeneous structure [11]. In addition, in developing countries, this examination is recommended in place of the other imagery which is expensive because of its availability and its cost-effectiveness [9]. Therapeutically, marginal excision is the treatment of choice. The excision must be as complete as possible in order to minimize the risk of local recurrence which remains exceptional (4\%) [12]. Liposuction alone does not allow complete resection or histopathological evaluation of the tumor [13]. Steroid injections are reserved for small lipomas. Surgical documents must be sent systematically to the histology laboratory for careful study. Indeed, histologically, they must be distinguished from liposarcomas. Typically, this study shows a thin peripheral capsule surrounding a lobular proliferation of adipocytes [8]. The distinction between a lipoma and a well-differentiated liposarcoma (LSBD) can be much more complex [14]. Well-differentiated liposarcomas are low-grade lipoma-like malignancies, hence the name "lipoma like" [3]. This differentiation is however fundamental for the patient's prognosis and management. According to some authors, liposarcoma develops at the expense of primitive mesenchymal cells rather than at the expense of adipocytes. It would therefore never develop on a preexisting lipoma [15, 16]. However, it has recently been reported in the literature a case of liposarcoma developed on the site of excision of a lipoma attesting that liposarcomas can arise from benign lipomas [17]. Lipoma being considered as benign with essentially no risk of malignancy. Surgical excision of a lipoma is often a definitive treatment modality [18]. On the other hand, the basic treatment of liposarcomas remains at present broad surgery with a carcinological aim. Their development is characterized by the occurrence of local recurrences and metastases, which makes their prognosis formidable [19].

\section{CONCLUSION}

Giant lipoma is a benign tumor that requires treatment because of the functional and social discomfort it causes. This tumor does not degenerate and does not give metastases but it can recur. The fear of a liposarcoma must have an anatomopathological examination of the part performed, in particular in the event of a tumor larger than $5 \mathrm{~cm}$.

\section{REFERENCES}

1. Zaroo M, Bashir SA, Mohsin M, Farooq PU, Farooq SA, Zargar HR. Giant Lipoma: A Case Report. JIMA: Volume jima.imana.org. 2011; 43, 77.

2. Efstathios C, Nikolaos P, Christos K, Alkis K, Spyros P, Ioannis N. Patient presenting with lipoma 
of the indexfinger: a case report. Cases Journal. 2010, 3:20.

3. Fuchs A, Henrot P, Walter F, Iochum S, Vignaud JM, Stines J, Blum A. Tumeurs graisseuses des parties molles des membres et des ceintures de l'adulte. J Radiol. 2002; 83:1035-57.

4. Verdin V, Preud'homme L, Lemaire V, Jacquemin D. Lipome géant dorsal. Rev Med Liège. 2009; 64:414-7.

5. Hasija Shweta, Khoiwal Susheela, Bilwal Bharat. Vulvar Lipoma-A Rare Case Report, American Journal of Medical Case Reports. 2015, 3(12), 413414.

6. Slim Dabloun, Myriam Khechimi, Abdessalem Jenzeri, Riadh Maalla : Lipome géant $\mathrm{du}$ dos à propos d'un cas. Annales de Dermatologie et de Vénéréologie Volume 142, $\mathrm{n}^{\circ}$ 6-7S2 page 353, Juin 2015.

7. Ouzaa MR, Youssef J, Bennis A, Zadoug O, Zine A, Tanane M, Benchakroun M, Jaafar A. Les lipomes géants des parties Molles: A Propos de Cinq Cas et Revue de la Littérature Marocaine de Chirurgie Orthopédique et Traumatologique N: 76 Année. 2018, 57.

8. Ouadii Al Haderi, Maria Bamohamed, Ilham Boughaza, Amina Tber, Abdelaziz Baidada, Najia Zeraidi, Aicha Kharbach: VulvarLipoma: Case Report, International Annals of Medicine. 1;1(5); 2017.

9. Sofia Jayi, Meriem Laadioui, Hind El Fatemi, Fatima ZohraFdili, Hakima Bouguern, Hikmat Chaara, Afaf Laamarti and My Abdelilah Melhouf: Vulvarlipoma: a case report, Jayi. Journal of Medical Case Reports. 2014, 8: 203.

10. Sherer DM, Gorelick C, Wagreich A, YC Lee, Serur E, Zigalo A and Abulafia O. Sonographic findings of a large vulvarlipoma, Ultrasound Obstet Gynecol Published online 30 August 2007 in Wiley Inter Science. 2007;30:786-787

11. Razafimanjato NNM, Rakotonaivo MJ, Rakotoarisoa AJC, Rakototiana AF, Hunald FA, Rakotovao HJL: Lipomegéant de la paroithoracique à propos d'un cas. Revue Tropicale de Chirurgie. 2013; 7: 15-16.

12. Fnini S, Hassoune J, Largab A. Lipome géant de la main. Chir Main. 2010; 29: 44-7.

13. A T Odoi, A Owusu-Bempah, E T Dassah, D E Darkey and S E Quayson: Vulvar Lipoma: Is It So Rare Ghana Med J. 2011 Sep; 45(3): 125-127.

14. Ouzaa MR, Youssef J, Bennis A, Zadoug O, Zine A, Tanane M, Benchakroun M, Jaafar A. Les Lipomes Géants des Parties Molles : A Propos de Cinq Cas et Revue de la Littérature Revue Marocaine de Chirurgie Orthopédique et Traumatologique $\mathrm{N}^{\circ}$ 76, Année. 2018 p 57.

15. Dumont Thierry, Simon E. Pathology's hypertrophiques des tissus graisseux de la face. RevStomatol Chir Maxillofac. 2006; 107(5):35460.

16. Inaba Hiroto, Furuta Yochikau, Usuda R, Ohta S, Nakajima N, Muro H, Kyobu Geka. Liposarcoma originating in the neck and the mediastinum after removal of mediastinal lipoma. The Japanese Journal of Thoracic Surgery. 2004; 57(10): 935-40.

17. Mssrouri Rahal, Benamr Said. Liposarcome Cervico-mediastinal. Feuillet de radiologie. 2006; 46(5):349-53.

18. Mentzel T. Cutaneouslipomatousneoplasms. Semin Diagn Pathol. 2001; 18: 250.

19. Houari Soufia. Aspects anatomopathologiques des liposarcomes à propos de $10 \mathrm{cas}$, thèse de médecine Maroc $\mathrm{N}^{\circ}$ 061/10, 87-88. 